\title{
Development and Alpha Testing of EzHifz Application: Al-Quran Memorization Tool
}

\author{
Nor Musliza Mustafa, ${ }^{1}$ Zulkifly Mohd Zaki ${ }^{1},{ }^{2}$ Khairul Anuar Mohamad, ${ }^{3}$ \\ Mokmin Basri, ${ }^{1}$ and Sedek Ariffin ${ }^{4}$ \\ ${ }^{1}$ Faculty of Science and Information Technology, Kolej Universiti Islam Antarabangsa Selangor, Bandar Seri Putra, \\ 43000 Kajang, Selangor, Malaysia \\ ${ }^{2}$ Faculty of Science and Technology, Universiti Sains Islam Malaysia, Bandar Baru Nilai, 71800, Nilai, Negeri Sembilan, Malaysia \\ ${ }^{3}$ Faculty of Quranic and Sunnah Studies, Universiti Sains Islam Malaysia, Bandar Baru Nilai, 71800, Nilai, Negeri Sembilan, Malaysia \\ ${ }^{4}$ Department of Al-Qur'an and Al-Hadith, Academy of Islamic Studies, Universiti Malaya, 50603, Kuala Lumpur, Malaysia
}

Correspondence should be addressed to Zulkifly Mohd Zaki; zulkifly@usim.edu.my

Received 21 January 2021; Revised 19 April 2021; Accepted 1 May 2021; Published 11 May 2021

Academic Editor: Christos Troussas

Copyright (C) 2021 Nor Musliza Mustafa et al. This is an open access article distributed under the Creative Commons Attribution License, which permits unrestricted use, distribution, and reproduction in any medium, provided the original work is properly cited.

\begin{abstract}
Learning to memorize the Quran presents a challenge. This paper reports the development and alpha testing of a mobile application called "EzHifz" for Quran memorization based on the VARK learning style. The application received positive feedback for user acceptance testing and heuristic testing. The Fleiss kappa coefficient $(\kappa)$ results for user acceptance testing show a very good level of agreement $(\kappa=0.850)$. Heuristic testing results show that $\kappa=0.731$ for content, manual guide, memorization activities, performance information, and tasmik assessment attributes, while $\kappa=0.727$ for presentation design, interactivity, multimedia elements, attraction, and motivation attributes. These results show a good level of agreement, which indicates that the EzHifz application meets the requirements of design and development based on the attributes evaluated. A combination of memorizing techniques in the application helps strengthen the use of preferred VARK learning styles. The techniques support the use of multiple senses that could facilitate the process of memorizing the Quran independently. This study contributes to the novel design and evaluation of the Quran memorization application based on the Quran memorization model. The application supports the teaching and learning of Quran memorization where it allows students to select their preferred VARK learning style with the technique of memorizing the Quran. This mobile application learning approach based on VARK's learning style has the potential to be implemented in the process of memorizing the Quran as well as retaining memory through the use of memory senses in support of the learning materials developed.
\end{abstract}

\section{Introduction}

Innovations of mobile digital in teaching and learning bring a substantial transformation in the field of education [1]. Mobile learning activities were able to develop an idea and creativity [2] that support unique pedagogical features through social and collaborative learning media. Recent studies indicate that applying mobile technology in learning Quran has shown positive support among the younger generation [3-6]. Providing the right teaching aids for students could impact students' performance levels as it facilitates the understanding of learning. Aligned with this, many previous researchers such as [7-11] have developed interactive mobile applications to help facilitate the process of memorizing and reciting the Quran. The development of the educational application through the process of understanding the systematic teaching design concepts with the right theory and technology of learning can enhance student learning outcomes [12]. However, it is undeniable that learning media that relate to the Quran memorization need a teacher as a complement to the perfect learning process [13].

Furthermore, the determination of students' dominant VARK learning styles is important to be emphasized to ensure the knowledge acquisition works well according to 
their multiple intelligence [14]. Therefore, the mobile application of Quran memorization based on the VARK learning style is important to be developed as one of the complementary learning tools in the context of Quran memorization (per word). Quran memorization (per word) involves memorizing the Quran verses with the corresponding translation.

This paper is structured in the following way. Section 2 provides the issues faced by the institution related to memorizing the Quran. Section 3 will discuss the related works, while Section 4 explains the methods and materials used in this research. Section 5 reveals the screen design of the EzHifz application as well as the alpha testing results. Finally, the conclusion and future work are given in Section 6.

\section{Issues in Quran Memorization}

Memorizing the Quran is often considered a difficult skill to learn because it requires a strong memory with a discipline of continuous repetition. Several studies were conducted by previous researchers to develop effective memorization methods [15-19], however, still many students not being able to memorize the Quran well. Many studies found difficulties in memorizing the Quran because of confusion and misunderstanding of the Quran's meaning, weak memories, disturbances from the environment, and problems in mastery of the Quran [20-22]. The level of Quran memorization among students in Darul Quran (an institute of Quranic Studies in Malaysia) also does not comply with their goal due to the lack of specific memorization techniques [7]. Tahfiz educational teachers need to be proficient in their Quran teaching methods and strategies through technological approaches [23] as well as identifying student learning styles to acquire knowledge [24]. However, most Tahfiz institutions applied the same Quran memorization method to the students without considering their students' learning styles. This is because different learners may require different approaches to memorize the Quran.

Recently, there has been an interest in memorizing the Quran due to the parental demand for their children to memorize the Quran. However, in the Tahfiz school curriculum, many students are unable to memorize all 30 juz within 3 years [25]. There were four issues emphasized in Tahfiz Model Ulul Albab (TMUA) curriculum approaches [25]. This includes (a) the incapability of students to memorize 30 juz of Quran within 3 years; (b) students' inability to apply the memorization technique; (c) emphasizing on the language as the learning strategy mechanism; and (d) the existing mechanism that does not measure the memorization strategy. These issues can be seen through their different achievements in memorizing the Quran among each other as well as the selection of models and strategies applied in their Quran memorization learning.

\section{Related Work}

3.1. VARK Learning Style. The VARK model is a set of learning styles that involves the use of a variety of senses
[26]. This model contains four learning styles, namely, visual $(\mathrm{V})$, auditory $(\mathrm{A})$, reading $(\mathrm{R})$, and kinesthetic $(\mathrm{K})$. The following are four (4) features of the VARK learning style available to individuals: (i) individuals with a visual (V) tendency to learn through charts, diagrams, graphs, and symbols rather than words; (ii) individuals with aural/auditory tendencies (A) to learn through conversations, lectures, and discussions; (iii) individuals with a read/write (R) tendencies to learn through words and texts such as reports, assignments, essays, manuals, and slides; and (iv) individuals with kinesthetic $(\mathrm{K})$ tendencies to learn through experiences, training, and simulations in the form of demonstrations, videos, movies, case studies, and applications.

Using a dominant VARK learning that adopts appropriate learning strategies and techniques may successfully engage the students' learning to produce quality learning performance $[27,28]$. Teaching students with the right style of learning is essential as the students can easily understand what they are learning. Thus, this may help students improve their learning to achieve good performance.

3.2. Memorizing Techniques. There are several memorizing techniques suitable to be applied in memorizing the Quran based on the observation report [29]. They are summarized in Table 1.

3.3. Relevant Quran Memorization Application. The previous works related to this research have been reported and summarized in our concept paper [39]. The paper reported the main features of the application versus our proposed Quran memorization tool features. However, in this paper, we are extending the report on the memorization technique that has been adapted. This is shown in Table 2 .

It was found that most of the applications use repetition, open-close, and pointer/highlight techniques to facilitate the Quran memorization. Although some of the projects support the differences in individuals' VARK learning styles, however, it did not integrate with all memorizing techniques. Generally, these existing applications can show the text and play back the audio of the reciter with the looping method. Some of the applications also provide audio recording capabilities and memorization performance management. Therefore, there is a need for supplementary learning materials to support the Quran memorization based on VARK learning styles with other types of effective memorizing techniques.

The motivation of the EzHifz application design was driven by the Quran memorization model developed in [39]. It integrates the VARK learning style mode, sensory memory, short-term memory, and long-term memory. However, the model developed has yet to be evaluated. It is believed that the utilization of multiple senses may support the differences in student preferences in VARK learning styles. Consequently, it may improve the memorizing performance among the students. Thus, the foundation design and development of the prototype in this research are based on this model. 
TABle 1: Memorizing techniques.

\begin{tabular}{|c|c|}
\hline Technique & Description \\
\hline Repetition & $\begin{array}{l}\text { Recurrence or replication of process that helps in strengthening the memory of what is being learned as it is a well- } \\
\text { rehearsed method that helps to maintain the memory retention of the Quran for a long time [6,30,31]. Repetition of } \\
\text { hearing or seeing affects the short-term memory [32]. }\end{array}$ \\
\hline Keyword & A two-tier procedure to remember new words that have relevant components called acoustic and mental links [33]. \\
\hline Segmentation & $\begin{array}{l}\text { Breaking up a long string into smaller manageable elements and it is implemented in the information or symbolic } \\
\text { encoding for retaining long-term memory [34]. }\end{array}$ \\
\hline Visual map & Memorize facts through colored images; student can learn and memorize information easily through vision [35]. \\
\hline Open-close & $\begin{array}{c}\text { A method of opening and closing the mushaf (the written pages of the Quran) of the verse alternately while } \\
\text { memorizing the Quran [36]. }\end{array}$ \\
\hline $\begin{array}{l}\text { Highlight or } \\
\text { pointer }\end{array}$ & $\begin{array}{l}\text { A signaling principle in multimedia that improves learning when cues that highlight or point the essential materials } \\
\text { are added. This includes outlines, headings, and a pointer that highlight printed text such as using bolding, italics, or } \\
\text { underlining [37]. Even finger indicators are often used as indicators in the reading. }\end{array}$ \\
\hline Association & $\begin{array}{l}\text { A memorizing technique for students with high visual tendencies. There are three types of graphical use, namely, } \\
\text { migration maps, flowcharts, and contrast comparisons [38]. It helps students to remember well through the } \\
\text { compilation and remapping of images coupled with color elements. }\end{array}$ \\
\hline
\end{tabular}

TABLE 2: Relevant system/application and memorization technique(s) adapted.

\begin{tabular}{|c|c|}
\hline System/application & Memorization techniques adapted \\
\hline Al-Quran education module [40] & $\begin{array}{l}\text { The VARK learning style approach that integrates with the Differentiated Model of } \\
\text { Giftedness and Talent Theory (DMGT) based on bloom's taxonomy scope applied } \\
\text { the repetition technique in memorizing the Quran verse and translation. }\end{array}$ \\
\hline $\begin{array}{l}\text { Al-Mudarris Quran Software http://www.islamcity. } \\
\text { com/ }\end{array}$ & $\begin{array}{l}\text { Audio repetition technique, that is, the repetition of ranges of verse groups and } \\
\text { repetition of verses inside the group. Highlight/pointer technique: used to show the } \\
\text { audio recitation of verse number. }\end{array}$ \\
\hline $\begin{array}{l}\text { Live Quran Tutoring http://www.quraninteractive. } \\
\text { com }\end{array}$ & $\begin{array}{l}\text { Repetition technique used for memorizing the Quran verse that enables online } \\
\text { one-on-one tutoring with an Internet connection. }\end{array}$ \\
\hline E-Hafiz [41] & $\begin{array}{l}\text { Repetition technique used in the feature of recorded voices called Mel-Frequency } \\
\text { Cepstral Coefficient (MFCC) technique and that compared with experts voices } \\
\text { stored in the database. It will point out any mismatch on the word level. }\end{array}$ \\
\hline $\begin{array}{l}\text { Quran Memorization (Hifz) and Revision Software } \\
\text { http://www.qurantracker.com/ }\end{array}$ & $\begin{array}{l}\text { Audio repetition and highlight techniques using color-coding which allow the user } \\
\text { to track the start and end date for memorizing a new surah or surah by surah, } \\
\text { respectively. }\end{array}$ \\
\hline Quran Memorizer http://www.islamcity.com/ & $\begin{array}{l}\text { Repetition technique used with a selection and loop of range between the verses } \\
\text { one wishes to memorize. }\end{array}$ \\
\hline $\begin{array}{l}\text { Quran Memorization Program http://www. } \\
\text { imaanstar.com/ }\end{array}$ & $\begin{array}{l}\text { Audio repetition technique used with a selection and loop of range between the } \\
\text { verses one wishes to memorize. }\end{array}$ \\
\hline $\begin{array}{l}\text { Quran Memorization Online, http://www. } \\
\text { houseofquran.com/ }\end{array}$ & $\begin{array}{l}\text { Audio repetition and highlight techniques of verses. It groups active verses with a } \\
\text { simulation of a Quran teacher. }\end{array}$ \\
\hline
\end{tabular}

\section{Methods and Materials}

The research applied the ADDIE model [42]. This is because the primary concept of this model is structured and directed. It consists of five major phases which include Analysis, Design, Develop, Implement, and Evaluate. The analysis phase was conducted based on two types of analyses, namely, user analysis, and task analysis. These tasks were done through document review, questionnaires, and classroom observations. Fourteen students aged between 10 and 18 years from a Tahfiz Integration School in Sepang, Selangor, Malaysia, were involved in this phase. User analysis focused on understanding of the teaching methods used by teachers, Quran memorization methods practiced by the students, and their VARK learning styles, as well as their knowledge on using mobile devices as a tool for teaching and learning. Task analysis focused on the content of learning, instructional requirements, and learning outcomes. At the end of this phase, a list of user requirements was gathered.

In the design phase, a paper-based interface was designed grounded on the syllabus content, manual guide, and activities of Quran memorization. Multimedia presentation elements such as image, audio, video, and text are added and applied to the interactivity of each button provided. The integration of seven memorizing techniques was designed based on the VARK learning style in the process of Quran memorization.

During the development and implementation phase, the flowchart and storyboard were developed to show the entire process of the Quran memorization technique in the application (App) prototype. In the development of the prototype, multimedia elements were integrated with the 
memorizing techniques based on the VARK learning style. The implementation output will be further explained in Section 5.

Alpha testing was carried out in the evaluation phase. In this evaluation, it was done with the experts only. This evaluation aims to obtain responses from these experts for improvements to the application developed before the application is being tested with a wider community. The user acceptance test [43,44] and heuristic testing [45] were conducted to acquire feedback and suggestions to improve the functionality of the application. Two groups of participants were involved in this evaluation. Group A consists of three experts in Quran memorization and group B consists of three experts in the educational technology field. All participants have been working in their respective areas for more than 20 years, publishing journals as well as performing teaching in their respective fields.

Each participant was provided with the EzHifz application prototype and evaluation form to respond to any errors and weaknesses of the application. A digital recorder was used to capture the verbal feedback from the participants. The user acceptance test instrument uses a scale of "Pass" or "Fail" while the heuristic testing instrument uses a scale of agree (Yes) or disagree (No). The user acceptance test aimed to examine the functions of the interactive buttons and navigation procedures as well as record status after the application is closed. It consists of a list of 54 items conducted with group A participants (see Appendix 1). The heuristic testing instrument consisted of 38 items that were used for group A (see Appendix 2), while 48 items were used for group B (see Appendix 3) to test the application. For group A, the items were developed based on the aspects of its content, manual guide, memorization activities, performance information, and evaluation of tasmik (teacher guides, listens, and records the progression of memorizing the Quran individually). However, group B items were focused on the aspects of presentation design, interactivity, multimedia elements, attraction, and motivation. During the testing session, all participants went through the application. Feedback was given by them at the end of the session. The test session was conducted within an hour.

Materials for EzHifz application development include software and hardware. Adobe Photoshop and Illustrator were used for graphical editing. Action Script, HTML, and JavaScript were used for programming applications, SQLite was used for a database application, Garage Band and Adobe Premiere were used for audio and video editing, respectively, and BlueStack was used for Android applications. The hardware was in the form of PCs, laptops, and smartphones.

\section{Results and Discussion}

5.1. Screen Design. The EzHifz application prototype is a standalone application that was developed for the Android platform. It is an offline application to facilitate individual students to freely access the application without an Internet connection. Surah Al-Insan (verse 76:1-31) from the Quran is used as the content of the prototype. The application contains several graphical user interfaces (GUI) such as home screen, main menu, profile menu, memorization menu, tasmik menu, and performance menu. The following describes each of the user interfaces in the EzHifz application.

Figure 1 shows the home screen when the application is first launched. EzHifz's contents were developed in Bahasa Malaysia, the official language of Malaysia. Students may click on the screen to proceed to the main menu. The main menu is shown in Figure 2.

In the main menu, the students are provided with four options, that is, memorization menu (HAFAZAN), performance menu (PRESTASI), tasmik menu (TASMIK), and profile menu (PROFAIL). The remainder of this section will discuss those options.

5.1.1. Profile Menu. The profile menu requires students to fill in their personal information such as name (NAMA HUFFAZ), age (UMUR), gender (JANTINA), phone (HUBUNGI), e-mail and category (KATEGORI) (either admin, teacher or student), and class (KELAS) as shown in Figure 3.

5.1.2. Memorization Menu. Figure 4 shows the memorization menu with a full learning mode $(\mathrm{V}, \mathrm{A}, \mathrm{R}$, and $\mathrm{K})$ being activated. It includes multimedia elements such as images, audio, video, and text. This is where the idea of VARK learning style and memorizing techniques is being integrated.

Integrating the VARK learning style with memorizing techniques such as repetition, keyword, segmentation, visual map, open-closed, pointer, highlighting, and association was implemented in the application to support the process of Quran memorization. The visual mode (V) depicts the translation of the meaning of the Quran verses applying segmentation and association techniques through dividing the verse into two or three small segments of colored objects or images (see the upper right corner of Figure 4). The audio mode (A) can be controlled by using the play-pause or playstop button. This enables a segmentation technique to be implemented while clicking the text or the Quran verse. It may help the student to control the process of memorizing lengthy Quran verses. The reading mode $(\mathrm{R})$ includes the Quran verse and translation in the form of text that also applies segmentation and pointing or highlight techniques. The kinesthetic mode (K) provides a feature of a video of Quran verses using the movement of body motion and gesture. It shows a step-by-step drawing of images using a segmentation technique to enable students to refer to the movement shown in the kinesthetic submenu in Figure 5.

The open-closed technique is applied to the V, A, R, and $\mathrm{K}$ buttons labeled at the right-hand side of the interface. This is to enable the memorization of verses according to individual preferences. For example, if a student wishes to use the visual and reading ( $\mathrm{V}$ and $\mathrm{R}$ ) mode as the preference of memorizing the verse, then this option can be activated by clicking $\mathrm{V}$ and $\mathrm{R}$ buttons. Upon clicking the buttons, the visual and reading modes will appear in the interface as shown in Figure 6. 


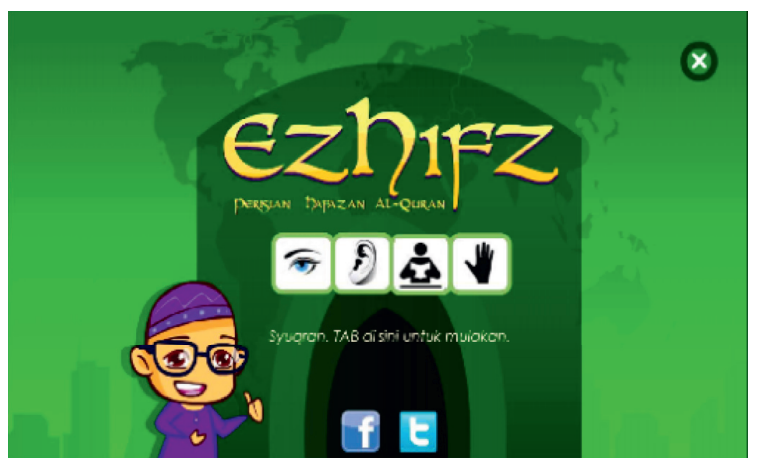

Figure 1: Home screen.

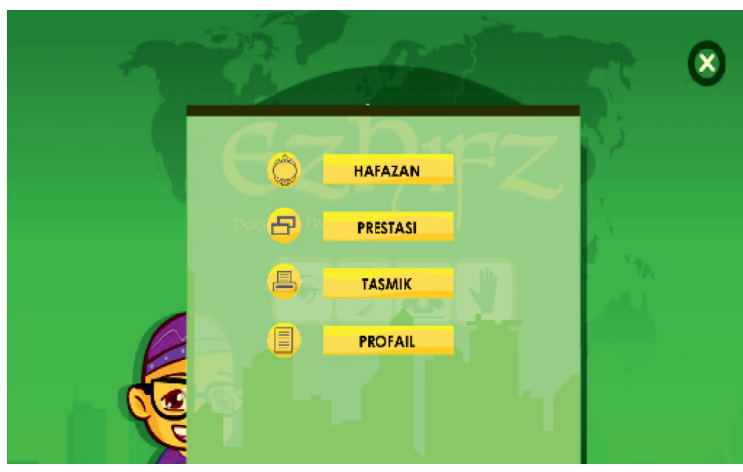

Figure 2: Main menu.

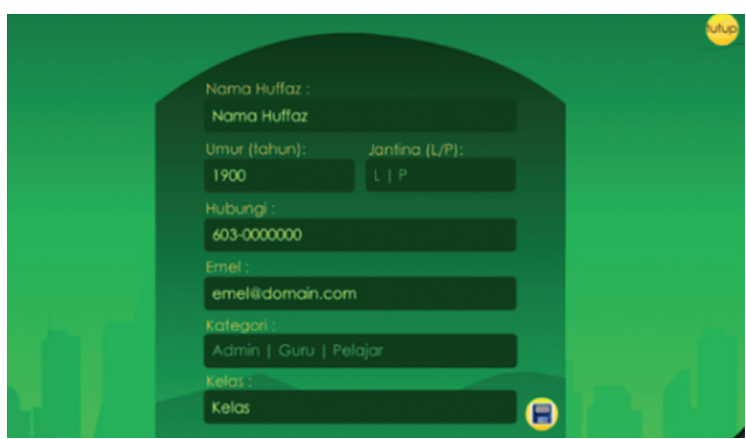

Figure 3: Profile menu.

The visual map submenu combines all Quran verses in a single interface with an iconic text and image as a keyword. This is to allow easy navigation between verses either to recall or memorize the Quran. This is shown in Figure 7. Students can freely select the verse that he/she wishes to start or continue to memorize from this submenu.

The performance indicators are also displayed using red, blue, and green colors. These colors serve as a guide to indicate which verses need attention from the student. Red indicates that there is more than one mistake that occurred when the student memorized the Quran. Blue indicates that memorizing has been improved; however, still there is at least one mistake that occurred, while green indicates that there is no mistake. These color indicators are based on the input given by the teacher during the tasmik session.

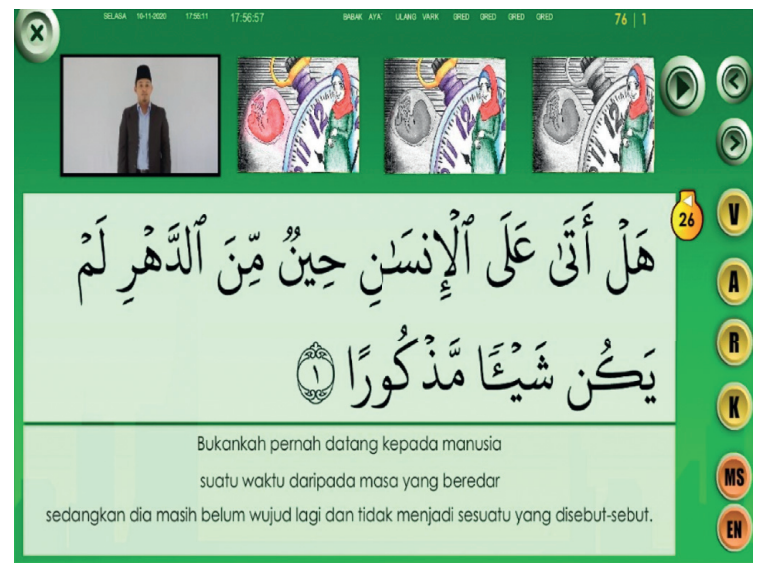

Figure 4: Memorization menu.

5.1.3. Tasmik Menu. Figure 8 shows the tasmik menu. This menu is provided to the teachers to mark the student performance. Tasmik is one of the typical methods used by a teacher to track their students' progress in Quran memorization. Attributes like the date (TARIKH), surah's name (SURAH), verse number (AYAT), mode of learning (VARK), number of repetitions (ULANGAN), duration (TEMPOH), grade (GRED), and status are provided. A selection of grade buttons (such as A, B, C, D, and E) is given by the teacher to determine the student's current performance in memorizing each of the Quran verses. These grades are equivalent to the "status" which is represented in color. Grade A is equivalent to green color and grade $B$ is equivalent to blue, while grade $C$ and beyond will be represented by red color. A teacher can access the menu by using a password as authentication. This is to maintain the integrity of the grades.

5.1.4. Performance Menu. Figure 9 shows the performance menu that displays the report of the student's evaluation. It tracks the date (TARIKH), surah's name (SURAH), verse number (AYAT), mode of learning (VARK), number of repetitions (ULANGAN), duration (TEMPOH), and performance status. The performance is indicated in color. The green dot represents grade A, i.e., Mumtaz (Excellent), the blue dot represents grade B, i.e., Jayyid (Good), and the red dot represents grade $\mathrm{C}$ and beyond, i.e., Maqbul (Acceptable). As mentioned earlier, the performance data in this report were derived from the tasmik session where the student is evaluated by the teacher.

5.2. Alpha Testing. In this section, the results of the alpha testing are discussed in detail. Overall, the testing performed by the participants showed a positive result, although there were suggestions given for improvement. Descriptive statistics were calculated for quantitative measures. Audio recordings and open-ended responses were also reviewed. These are reported in the remainder of this section.

5.2.1. User Acceptance Test. The data of each of the attributes were measured and analyzed based on the index of 

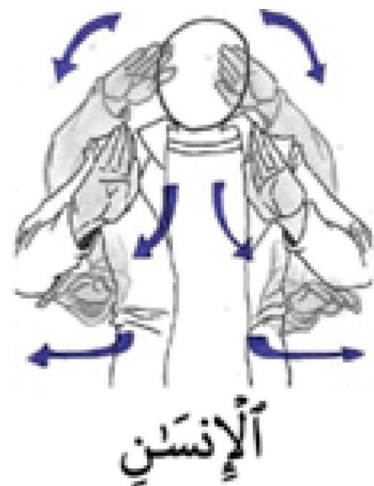

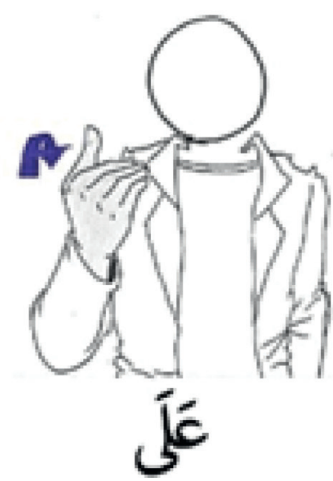

FIGURE 5: Kinesthetic submenu.

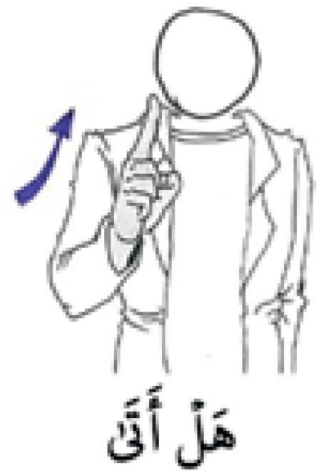

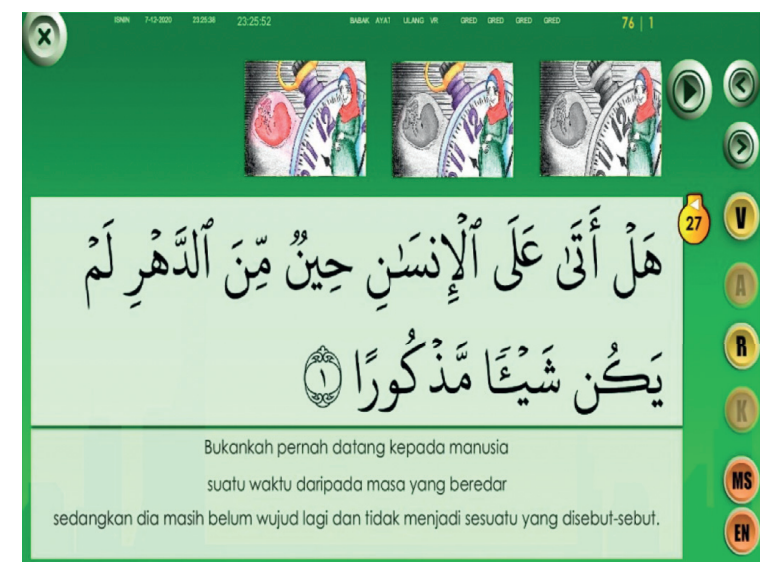

Figure 6: VARK Memorization interface showing only " $V$ " and "R" modes being activated.

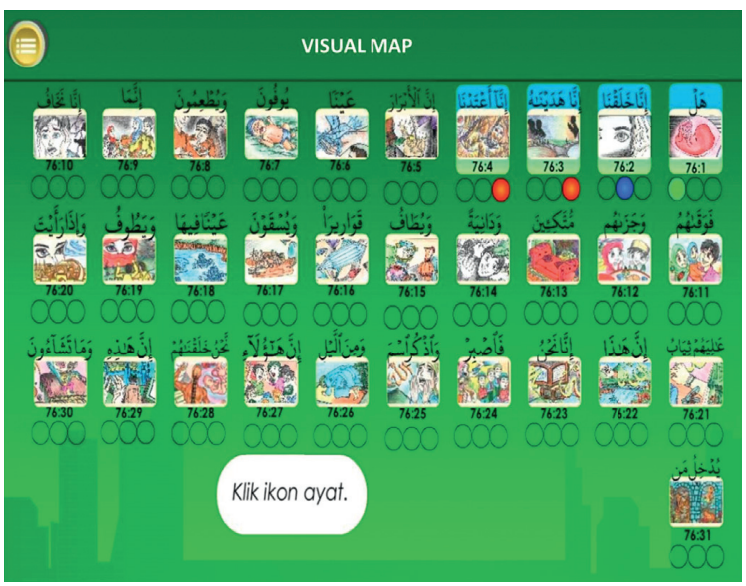

Figure 7: Visual map submenu.

agreement using the Fleiss kappa coefficient $(\kappa)$, which was an extension of Cohen's kappa introduced by Cohen [46]. Fleiss' kappa [47-49] is a measure of interrater agreement between two or more raters using data in a nominal scale to determine the level or strength of agreement. The ratings are divided into five categories as shown in Table 3.

Group B participants were engaged in carrying out the user acceptance test. Table 4 shows the analysis of the participants' feedback from the user acceptance test.
The results show that the EzHifz application developed is functioning well for the two attributes, namely, the interactive buttons and navigation, as well as the status recorded after the application is closed. The results show that the participant agreement is very good $(\kappa=0.850$, i.e., three participants did agree). This shows that the majority of the participants provide a very good level of agreement concerning the user acceptance test based on the attributes evaluated. 


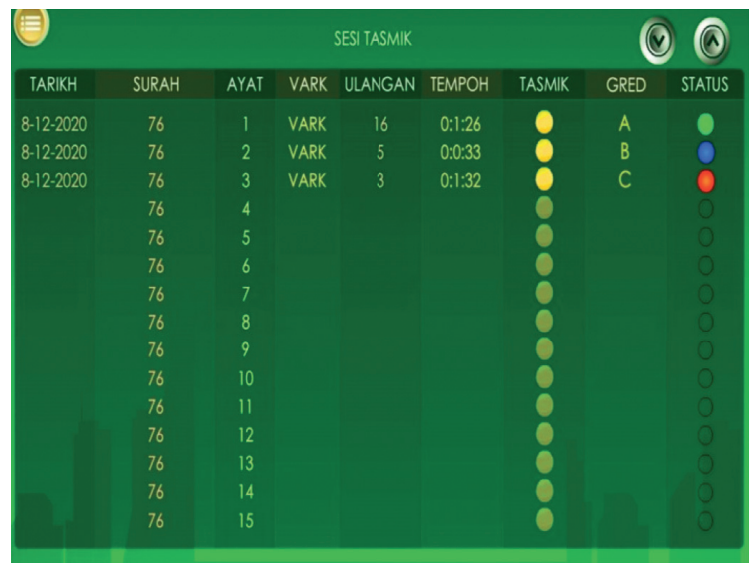

Figure 8: Tasmik menu.

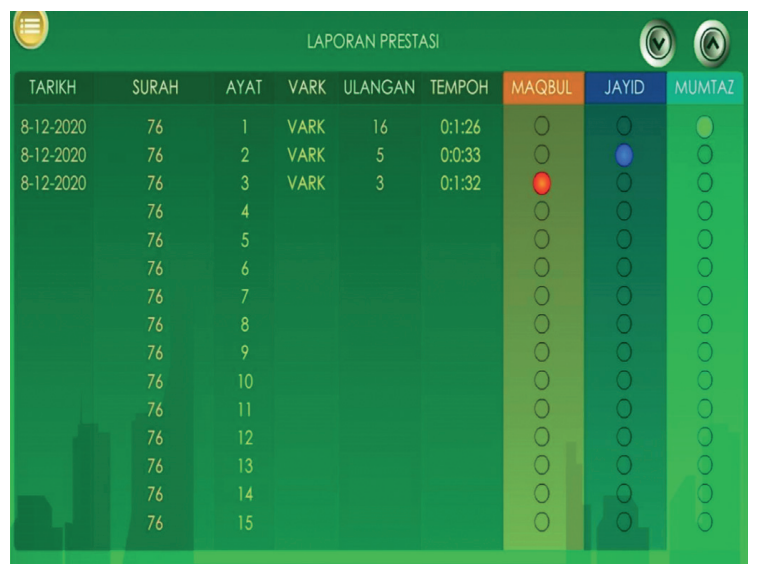

FIgURe 9: Performance menu.

TABLE 3: Classification of Cohen's kappa.

\begin{tabular}{lc}
\hline Value of $\kappa$ & Strength of agreement \\
\hline$<0.21$ & Poor \\
$0.21-0.40$ & Fair \\
$0.41-0.60$ & Moderate \\
$0.61-0.80$ & Good \\
$0.81-1.00$ & Very good \\
\hline
\end{tabular}

Source: Cohen (1960).

5.2.2. Heuristic Testing. As mentioned in Section 4, six (6) participants were engaged in the heuristic testing of the EzHifz application prototype. They are from group A and group B. Table 5 shows the analysis of the participants' feedback from the attributes provided in the heuristic testing.

The results show that both groups agreed that the EzHifz application meets the requirements of design and development based on the attributes evaluated. Group A and group B evaluations show Fleiss's kappa values of 0.737 and 0.727 , respectively. These results show that the majority of the participants provide a good level of agreement of attributes for the items evaluated.
The general comments from both groups regarding the content and design of the application were also collected. The following are the three key comments and suggestions from these participants for the betterment of the application.

(1) Clear and precise instruction for using the application environment is required.

Although they liked the overall concept of selecting "VARK buttons" (i.e., that allow the user to choose their preferred VARK learning style) for the focusing strategies of learning memorization skills, the participants recognized that our intended users are inexperienced in the new technique introduced in the application. Some comments from them include the following:

"...providing a narrator and/or "help" icon in each interface could assist users to easily navigate in the application environment."

"either a demonstration or clear coaching from a researcher would be required to reduce confusion in differentiating between the four modes of learning."

It is noted that the user requires precise instructions when using a new application. These instructions may help users to navigate and use the application. Availability of options like a video demonstration or a help page on using the application may be a way forward to address this issue. However, this needs to be further studied before a decision can be made.

(ii) Allow the application to be more engaging by strengthening teaching and learning.

One of the participants suggested

"... being able to build a module and training about the flow of the process in the Quran memorization application learning is important so that it will not deviate students from the learning objectives."

"The selection and personalization of the character of the user in terms of their VARK learning style is a way to increase the user application engagement."

All participants agreed that having a choice of the VARK learning style in memorizing the Quran will give options of learning approach for the students to use the application effectively. This availability may be further enhanced by personalizing the application according to the user preferences. This seems to be a good enrichment that could be brought to the application.

(iii) Allow the application to be more attractive through effective design.

Several comments were focused on the design and functionality of the multimedia elements used. Below are their comments:

"The application should meet the standard interface in the aspect of color, buttons and text." 
TABLE 4: Data analysis of user acceptance test.

\begin{tabular}{|c|c|c|c|c|}
\hline \multirow{2}{*}{ Attributes } & \multicolumn{2}{|c|}{ Pass } & \multicolumn{2}{|c|}{ Fail } \\
\hline & Frequency & $\%$ & Frequency & $\%$ \\
\hline \multirow{3}{*}{ Function of interactive buttons and navigation } & 46 & 93.88 & 3 & 6.12 \\
\hline & 47 & 95.92 & 2 & 4.08 \\
\hline & 47 & 95.92 & 2 & 4.08 \\
\hline \multirow{3}{*}{ Record status } & 5 & 100 & 0 & 0 \\
\hline & 5 & 100 & 0 & 0 \\
\hline & 5 & 100 & 0 & 0 \\
\hline
\end{tabular}

TABle 5: Data analysis of heuristic testing.

\begin{tabular}{|c|c|c|c|}
\hline Participants & Attributes & Fleiss's Kappa coefficient $(\kappa)$ & Strength of agreement \\
\hline Group A & $\begin{array}{c}\text { Content } \\
\text { Manual guide } \\
\text { Memorization activities } \\
\text { Performance information } \\
\text { Tasmik assessment }\end{array}$ & 0.737 & Good \\
\hline Group B & $\begin{array}{c}\text { Presentation design } \\
\text { Interactivity } \\
\text { Multimedia elements } \\
\text { Attraction } \\
\text { Motivation }\end{array}$ & 0.727 & Good \\
\hline
\end{tabular}

".. should have an introductory to inform the user of the objective of using the application."

"The images in the visual mode should differentiate the changing of the color between the segmentation technique used in Quran verses and the translation."

Our first impression was that the application is simple when it was built. However, for a new user who is unfamiliar with the application, a step-by-step guide is still required to navigate and use the application. This implied that a thorough study is needed on the application design before a design decision can be made.

\section{Conclusion and Future Work}

Overall, the alpha testing conducted helped to improve the quality of the application. This application has been designed and developed as a tool to evaluate the Quran memorization model presented in [39]. The evaluation results proved that it is possible to integrate the VARK learning style with memorization techniques. Choosing the right VARK student learning style inclination in using the application may create a stimulating and effective learning environment for students.

The development of an attractive application interface also may enhance students' motivation as well as features that are easily accessible offline. The application also allows for the selfexploration of learning without the help of a teacher. This model may be suitable to be implemented in other domains that have a similar practice to this study; however, further studies are needed to be done to confirm this claim.
The next stage of this research is to leverage the comments captured from the participants. Improvements to the application will be done and the prototype will be evaluated with a group of potential students to study the usability of the application. This includes assessing the efficiency, effectiveness, learnability, acceptability, and user satisfaction towards the application in a real environment to aid the Quran memorization among students.

\section{Data Availability}

The data generated or analyzed during this study are included within this article.

\section{Conflicts of Interest}

The authors declare that they have no conflicts of interest.

\section{Acknowledgments}

This work was supported by the Universiti Sains Islam Malaysia (USIM) (PPPI/FST/0118/051000/14718).

\section{Supplementary Materials}

Appendix 1 shows the details of the user acceptance form for the EzHifz application. Appendix 2 and Appendix 3 show the details of the heuristic testing form for Quran Memorization Content Expert and Educational Technology Expert, respectively, that were given during the evaluation. (Supplementary Materials) 


\section{References}

[1] A. Oke and F. A. P. Fernandes, "Innovations in teaching and learning: exploring the perceptions of the education sector on the 4th industrial revolution (4IR)," Journal of Open Innovation: Technology, Market, and Complexity, vol. 6, no. 2, p. 31, 2020.

[2] I. Jahnke and J. Liebscher, "Three types of integrated course designs for using mobile technologies to support creativity in higher education," Computers \& Education, vol. 146, Article ID 103782, 2020.

[3] F. Y. Mustaffa, A. R. Salam, N. H. Mohd Sharif, A. Sirri, and A. H. Abdullah, "Needs and preferences of Qur'anic Arabic vocabulary learners regarding learning through Qur'anic Arabic mobile applications," International Journal of Psychosocial Rehabilitation, vol. 24, no. 5, pp. 152-162, 2020.

[4] L. Fanani, K. C. Brata, A. H. Brata, and M. A. Fauzi, "Usability evaluation of mobile-based application for Al-Quran writing learning with gamification," in Proceedings of the 2019 International Conference on Sustainable Information Engineering and Technology (SIET), pp. 276-279, Lombok, Indonesia, September 2019.

[5] S. Fitriah Ishak, Z. Mohd Zaki, K. Anuar Mohamad et al., "Formative evaluation of an educational mobile application: an interactive MyQiraat application," International Journal of Engineering \& Technology, vol. 7, no. 4.15, pp. 75-79, 2018.

[6] N. Senan, W. A. Wan Ab Aziz, M. F. Othman, and S. Suparjoh, "Embedding repetition (Takrir) technique in developing Al-Quran memorizing mobile application for autism children," MATEC Web of Conferences, vol. 135, Article ID 00076, 2017.

[7] M. H. Abdullah, Z. A. Aziz, R. H. A. Rauf, N. Shamsudin, and R. A. Latiff, "TeBook A mobile holy Quran memorization tool," in Proceedigns of the 2019 2nd International Conference on Computer Applications \& Information Security (ICCAIS), pp. 1-6, IEEE, Riyad, Saudi Arabia, May 2019.

[8] M. G. Musa, M. H. Y. Niyaz, M. M. Mohd Sopee, and N. A. Mohamad Ali, "I-tasmik mobile platform-enabling tahfiz students to memorize Al-Quran independently," in Proceedings of the 2018 International Conference on Information and Communication Technology for the Muslim World (ICT4M), pp. 24-29, IEEE, Kuala Lumpur, Malaysia, July 2018.

[9] S. F. Ishak, Z. M. Zaki, K. A. Mohamad, M. N. S. M. Sayuti, and M. A. Musa, "The design evaluation of an interactive Qiraat mobile application," Advanced Science Letters, vol. 23, no. 5, pp. 4631-4634, 2017.

[10] S. F. Ishak, Z. M. Zaki, K. A. Mohamad, M. A. M. Bahrin, N. H. A. Roni, and M. A. Musa, "MyQiraat: an interactive Qiraat mobile application," in Proceedings of the 2016 4th International Conference on User Science and Engineering (iUSEr), pp. 35-39, IEEE, Melaka, Malaysia, August 2016.

[11] M. Elobaid, K. Hameed, and M. Eldow, “Towards designing and modeling of Quran learning applications for android devices," Life Science Journal, vol. 11, no. 1, pp. 160-171, 2014.

[12] Y.-S. Chang, K.-J. Hu, C.-W. Chiang, and A. Lugmayr, "Applying mobile augmented reality (AR) to Teach interior design students in layout plans: evaluation of learning effectiveness based on the ARCS model of learning motivation theory," Sensors, vol. 20, no. 1, p. 105, 2019.

[13] D. Purbohadi, B. R. Rahmawati, and H. Setiyawan, "Development of Qur'an memorization learning model based on mobile learning," Journal of Physics: Conference Series, vol. 1381, Article ID 012029, 2019.
[14] A. Zainun, A. Che Endut, A. A. Ainuddin Wahid, A. R. K. Rustum Ali Khan, and A. F. Yazid, "Correlation study between learning style and multiple intelligence among Muslim gifted and talented," Abqari Journal, vol. 20, no. 2, pp. 56-66, 2019.

[15] U. Salamah, "Kaisa method in intelligence multiple perspective," HUNAFA: Jurnal Studia Islamika, vol. 16, no. 1, pp. 78-87, 2019.

[16] F. R. Pradhana, A. Musthafa, T. Harmini, and M. Dedy Setiawan, "Elayah: mobile based media for Al-Qur'an memorization using Takrar method," Journal of Physics: Conference Series, vol. 1381, Article ID 012025, 2019.

[17] H. Ahmad, N. M. M. Zainuddin, R. C. M. Yusoff, N. F. M. Azmi, and W. A. W. Hassan, "Augmented reality model to aid Al-Quran memorization for hearing impaired students," in Intelligent and Interactive Computing, V. Piuri, V. Balas, S. Borah, and S. Syed Ahmad, Eds., Springer, Singapore, pp. 447-457, 2019.

[18] M. M. Al Hafiz, M. F. Yusof, M. A. I. Ghazali, and S. S. Md. Sawari, "Descriptive qualitative teaching method of memorization in the institution of Tahfiz Al-Quran wal Qiraat pulai Condong and the students' level of academic excellence," Mediterranean Journal of Social Sciences, vol. 7, no. 1 S1, p. 79, 2016.

[19] S. Ariffin, S. Amir, M. Abdullah et al., "Effective techniques of memorizing the Quran: a study at Madrasah tahfiz Al-Quran, Terengganu, Malaysia," Middle-East Journal of Scientific Research, vol. 13, no. 1, pp. 45-48, 2013.

[20] N. Abdullah, F. S. Sabbri, and R. A. Isa, "Challenges and difficulties in memorizing the Qur'an in the tahfiz classes among secondary learners," Al-Burhan: Journal of Qur'an and Sunnah Studies, vol. 3, no. 2, pp. 1-14, 2019.

[21] H. Ishak, H. Mamat, M. F. Mohd Saad, and S. Mohamad, "Learning and student's achievement factors in j-QAF Khatam al-Quran model," Islamiyyat, vol. 41, no. 2, pp. 29-38, 2019.

[22] H. Radina and H. Zubaidillah, "Study of analysis of difficulties of elementary school children in memorizing the Koran, case study Mi Ummul Qura amuntai," in Proceedings of the 1st International Conference on Islamic and Social Education Interdisciplinary, pp. 71-88, Kuala Lumpur, Malaysia, February 2020.

[23] A. A. Y. AlZoubi, "Use of information technology in the teaching of Quran recitation (Qira'at)-electronic Miqrah as a Model," in Proceedings of the Taibah University International Conference on Advances in Information Technology for the Holy Quran and Its Sciences, pp. 593-621, IEEE, Al-Madinah, Saudi Arabia, December 2013.

[24] S. M. Magdalena, "The Relationship of Learning Styles, Learning Behaviour and Learning Outcomes at the Romanian Students," Procedia-Social and Behavioral Sciences, vol. 180, pp. 1667-1672, 2015.

[25] N. F. Ambo and S. E. Mokhsein, "Trend and issue in learning strategy of Tahfiz model ulul albab (TMUA)," International Journal of Academic Research in Business and Social Sciences, vol. 9, no. 7, pp. 1418-1426, 2019.

[26] N. D. Fleming, Teaching and Learning Styles: VARK Strategies, IGI global, Hershey, PA, USA, 2011.

[27] S. Muluk, H. Habiburrahim, and S. R. Rechal, "Students" awareness and perception towards learning styles," Jurnal Ilmiah Didaktika: Media Ilmiah Pendidikan dan Pengajaran, vol. 20, no. 2, pp. 143-164, 2020.

[28] N. Islam, M. Beer, and F. Slack, "E-learning challenges faced by academics in higher education: a literature review," Journal 
of Education and Training Studies, vol. 3, no. 5, pp. 102-112, 2015.

[29] N. M. Mustafa, Z. M. Zaki, K. A. Mohamad, M. Basri, and S. Ariffin, "Kaedah hafalan Al-Quran berasaskan kecenderungan gaya pembelajaran VARK (Translation: quran memorization method based on VARK learning style)," in Proceedings of the Seminar Antarabangsa Islam Dan Sains (SAIS 2018) (International Seminar on Islam and Science), pp. 1-10, Kajang, Malaysia, April 2018.

[30] S. Ariffin, M. Abdullah, and K. Ahmad, "Module of Al-Quran memorization according to capability and period," International Proceedings of Economics Development and Research, vol. 83, p. 82, 2015.

[31] M. Hamiz, M. Bakri, H. Haron, S. M. Sabri, and N. Jamil, "Repetitive memorization mobile application development for elderly memory recall," in Proceedings of the 2014 IEEE Conference on e-Learning, e-Management and e-Services (IC3e), pp. 150-155, Melbourne, Australia, December 2014.

[32] J. M. Olichney, C. Van Petten, K. A. Paller, D. P. Salmon, V. J. Iragui, and M. Kutas, "Word repetition in amnesia: electrophysiological measures of impaired and spared memory," Brain, vol. 123, no. 9, pp. 1948-1963, 2000.

[33] M. Pressley, J. R. Levin, and H. D. Delaney, "The mnemonic keyword method," Review of Educational Research, vol. 52, no. 1, pp. 61-91, 1982.

[34] O. Solopchuk, A. Alamia, E. Olivier, and A. Zénon, "Chunking improves symbolic sequence processing and relies on working memory gating mechanisms," Learning \& Memory, vol. 23, no. 3, pp. 108-112, 2016.

[35] M. A. Hazilah and M. Nur Haizum, "Gaya Pembelajaran dan Pencapaian Pelajar dalam kursus Reka Bentuk Aturcara (Translation: learning styles and students achievement in the programming design and problem solving course)," Jurnal Teknologi Maklumat dan Multimedia Asia-Pasifik (Asia-Pacific Journal of Information Technology and Multimedia), vol. 3, no. 2, pp. 1-12, 2014.

[36] S. Ariffin, "Kaedah menghafal Al-Qur'an di Institusi Tahfiz Al-Qur'an di Malaysia: Kajian perbandingan di antara kaedah Darul Quran, JAKIM dengan kaedah al-Huffaz (Translation: methods of memorizing the Quran in the institution of Tahfiz al-Quran in Malaysia: a comparative study between the method of Darul Quran, JAKIM and the method of AlHuffaz)," Doctoral dissertation, Jabatan al-Quran dan alHadith, Akademi Pengajian Islam, Universiti Malaya, Kuala Lumpur, Malaysia, 2012.

[37] J. Mestre and B. H. Ross, Eds., Cognition in Education, Academic Press, Cambridge, MA, USA, 2011.

[38] F. Anjomafrouz and G. Tajalli, "Effects of using mnemonic associations on vocabulary recall of Iranian EFL learners over time," International Journal of English Linguistics, vol. 2, no. 4, p. 101, 2012.

[39] N. M. Mustafa, Z. M. Zaki, K. A. Mohamad, M. Basri, and S. Ariffin, "The design of Quran memorization tool using lowfidelity prototype," in Proceedings of the 18th International Conference on Intelligent Software Methodologies, Tools and Techniques (SoMeT2019), pp. 430-443, Kuching, Malaysia, September 2019.

[40] A. B. A. Hilmi, Z. Zakariai, M. Spawi, A. N. T. Roslan, and M. K. Khalid, "The development of Al-Quran education module for gifted and talented students: Permata Insan College Approach, Al-Qanatir," International Journal of Islamic Studies, vol. 5, no. 2, pp. 22-33, 2017.

[41] A. Muhammad, Z. ul Qayyum, S. Tanveer, A. MartinezEnriquez, and A. Z. Syed, "E-hafiz: intelligent system to help
Muslims in recitation and memorization of Quran," Life Science Journal, vol. 9, no. 1, pp. 534-541, 2012.

[42] R. M. Branch, Instructional Design: The ADDIE Approach, Springer Science \& Business Media, Berlin, Germany, 2009.

[43] P. Pandit and S. Tahiliani, "AgileUAT: a framework for user acceptance testing based on user stories and acceptance criteria," International Journal of Computer Applications, vol. 120, no. 10, pp. 16-21, 2015.

[44] B. Hambling and P. Van Goethem, User Acceptance Testing: A Step-by-step Guide, BCS Learning \& Development, England, UK, 2013.

[45] M. R. Davids, U. M. E. Chikte, and M. L. Halperin, "An efficient approach to improve the usability of e-learning resources: the role of heuristic evaluation," Advances in Physiology Education, vol. 37, no. 3, pp. 242-248, 2013.

[46] J. Cohen, "A coefficient of agreement for nominal scales," Educational and Psychological Measurement, vol. 20, no. 1, pp. 37-46, 1960.

[47] J. L. Fleiss, F. J. L. B. Paik, and B. R. Levin, Statistical Methods for Rates and Proportions, p. 151, Wiley-Interscience, Hoboken, NJ, USA, 2003.

[48] J. L. Fleiss and J. Cuzick, "The reliability of dichotomous judgments: unequal numbers of judges per subject," Applied Psychological Measurement, vol. 3, no. 4, pp. 537-542, 1979.

[49] J. L. Fleiss, "Measuring nominal scale agreement among many raters," Psychological Bulletin, vol. 76, no. 5, pp. 378-382, 1971. 